\title{
The I Gene of Bean: A Dosage-Dependent Allele Conferring Extreme Resistance, Hypersensitive Resistance, or Spreading Vascular Necrosis in Response to the Potyvirus Bean common mosaic virus
}

\author{
Candace Whitmer Collmer, ${ }^{1}$ Marcia Fisher Marston, ${ }^{2}$ Jessica C. Taylor, ${ }^{1}$ and Molly Jahn ${ }^{3}$ \\ ${ }^{1}$ Department of Biological and Chemical Sciences, Wells College, Aurora, NY 13026 U.S.A.; ${ }^{2}$ Department \\ of Biology, Roger Williams University, Bristol, RI 02809 U.S.A.; ${ }^{3}$ Department of Plant Breeding and Bio- \\ metry, Cornell University, Ithaca, NY 14853 U.S.A. \\ Accepted 17 July 2000.
}

\begin{abstract}
The resistance to the potyvirus Bean common mosaic virus (BCMV) conferred by the $I$ allele in cultivars of Phaseolus vulgaris has been characterized as dominant, and it has been associated with both immunity and a systemic vascular necrosis in infected bean plants under field, as well as controlled, conditions. In our attempts to understand more fully the nature of the interaction between bean with the $I$ resistance allele and the pathogen $B C M V$, we carefully varied both $I$ allele dosage and temperature and observed the resulting, varying resistance responses. We report here that the $I$ allele in the bean cultivars we studied is not dominant, but rather incompletely dominant, and that the system can be manipulated to show in plants a continuum of response to $\mathrm{BCMV}$ that ranges from immunity or extreme resistance, to hypersensitive resistance, to systemic phloem necrosis (and subsequent plant death). We propose that the particular phenotypic outcome in bean results from a quantitative interaction between viral pathogen and plant host that can be altered to favor one or the other by manipulating $I$ allele dosage, temperature, viral pathogen, or plant cultivar.
\end{abstract}

Additional keywords: plant virus resistance, temperaturesensitive resistance.

The precise role of the hypersensitive response (HR) in resistance responses by plants to their pathogens has been a question of long-standing interest (Ponz and Bruening 1986; Culver et al. 1991; Matthews 1991; Goodman and Novacky 1994; Hammond-Kosack and Jones 1996; Dangl et al. 1996; Greenberg 1997; Yu et al. 1998). In typical hypersensitive resistance against plant viruses, necrotic local lesions appear on the inoculated leaf concomitant with the inhibition of the virus in the vicinity of the lesions; the virus is limited to the inoculated leaf and does not spread systemically. However,

Corresponding author: C. W. Collmer; E-mail: ccollmer@wells.edu what mediates that inhibition and exactly what role the HR plays are not yet fully understood. In plant-pathogen interactions that normally involve hypersensitive resistance, there are some clearly documented situations in which there is effective resistance without accompanying hypersensitive cell death (Takusari and Takahashi 1979; Yu et al. 1998). Conversely, there are examples of viruses or viral mutants that are not confined to the inoculated leaf even though the HR is induced (Matthews 1991; Culver et al. 1991). By constructing different mutants of Cucumber mosaic virus (CMV), Kim and Palukaitis (1997) have shown that the resistance to CMV in cowpea involves both a local HR and a viral inhibition response (IR) and that these two responses can be separated using different viral mutants. This separation of two different responses is supported by the phenotype of the Arabidopsis mutant $d n d 1$, in which there is loss of the HR but not resistance to the bacterial pathogen Pseudomonas syringae (Yu et al. 1998).

It is not surprising then that attempts to label plant viral resistance genes as hypersensitive, or not so, have encountered difficulties. Clearly there are some forms of resistance to viral pathogens that do not involve the HR. The term immunity refers to an "absolute state of exemption from infection" with a virus (Cooper and Jones 1983); there is no detectable replication and the virus cannot be recovered from the inoculated leaf. A classic example of this type of resistance is that against Cowpea mosaic virus due to interference with processing of viral polyproteins by a protease inhibitor in the cowpea cv. Arlington (Ponz et al. 1988). While immunity and typical hypersensitive resistance are readily distinguishable, attempts to delineate other categories of resistance responses between these two extreme classes have been problematic.

In potato, resistance and resistance genes were classified into two main types: necrotic or hypersensitive resistance, conferred by $N$ genes; and extreme resistance, showing very little or no visible effect, conferred by $R$ genes (Delhey 1975). However, the difficulties in reliably differentiating these two 
classes are readily apparent from the very derivation of the term extreme resistance, used by H. Ross when localized necrotic lesions were observed on Potato virus X (PVX)inoculated leaves of some plants previously called immune (Cockerham 1970). Even though potato breeders reported difficulties in scoring plants "accounted for by the difficulty in differentiating between [extremely] resistant individuals showing exceptional localised necrosis....and hypersensitive individuals showing little or no necrosis through physiological effects operating at the time of symptom production" (Cockerham 1970), the categories have persisted (Valkonen 1994) though they have not served the field particularly well. Thus, it was not surprising to find that a "hypersensitive response-like mechanism" [our italics] is involved in the extreme resistance in potato conferred by the $R y_{\text {sto }}$ gene against the potyviruses Potato virus $Y$ (PVY) and Tobacco etch virus (Hinrichs et al. 1998). Even the very strong extreme resistance to PVX in potato conferred by the $R x$ loci is associated with hypersensitivity in some cultivars and under some environmental conditions (Bagnall 1961; Bendahmane et al. 1999; Benson and Hooker 1960; Delhey 1974;). One of the conditions affecting hypersensitivity in plants with the $R x$ gene is temperature (Benson and Hooker 1960; Delhey 1974). The same is true for hypersensitivity exhibited in several other systems, e.g., the temperature sensitivity of the resistance response in $N$ gene tobacco inoculated with Tobacco mosaic virus (Ponz and Bruening 1986).

What emerges then, for many resistance genes, is a continuum of possible response in the reaction between virus and resistant plant that may include an effective hypersensitive resistance under some, but not all, conditions. Nowhere is this more clearly seen than in the interaction between the potyvirus Bean common mosaic virus (BCMV) and cultivars of Phaseolus vulgaris carrying the $I$ allele (Ali 1950), which is widely used in bean breeding as a source of resistance to BCMV. Plant breeders who first characterized this resistance reported apparent immunity in cv. Corbett Refugee to the virus (Pierce 1934) and agreed that the resistance was conferred by a single, dominant gene (Pierce 1935; Ali 1950). However, reports soon followed that an occasional plant developed systemic necrosis and died (Grogan and Walker 1948), and eventually it became clear (Ali 1950) that BCMV is also the causal agent for the "black root syndrome" previously described by Jenkins (1940, 1941). "Black root" symptoms include spreading, usually lethal, phloem necrosis seen under certain conditions in plants carrying the 'Corbett Refuge' type of resistance but never in susceptible plants, which exhibit mosaic symptoms, or in those with a different type of resistance (Grogan and Walker 1948). In our attempts to more fully understand the nature of the interaction between the $I$ resistance locus and the pathogen BCMV, we carefully varied both $I$ allele dosage and temperature and observed the resulting, varying resistance responses. We report here that the $I$ allele in the bean cultivars we studied is not dominant, but rather incompletely dominant, and that the system can be manipulated to show a clear continuum of response in these plants to BCMV that ranges from immunity or extreme resistance, to hypersensitive resistance, to phloem necrosis that spreads systemically and results in plant death.

These three types of response can be elicited reliably by mechanically inoculating three different $P$. vulgaris 'Black Turtle' genotypes (Fisher and Kyle 1994) with BCMV NY15 (isolate NY 68-95) at two different temperatures. When 'Black Turtle' plants homozygous for $I$, heterozygous $(I / i)$, or fully susceptible $(i / i)$ are inoculated with BCMV, a continuum of qualitatively different classes of plant response to the virus are observed (Table 1). Inoculating homozygous resistant plants $(\mathrm{BT}-1, I / I)$ with $\mathrm{BCMV}$ at $23^{\circ} \mathrm{C}$ elicits the extreme resistance against BCMV originally described for the $I$ locus; neither inoculated primary leaves nor uninoculated upper trifoliates show detectable symptoms, and no coat protein can be detected in those leaves using direct double-antibody sandwichenzyme-linked immunosorbent assay (Clark and Adams 1977). In this case, there is an effective viral IR but no visible HR. However, by changing either the plant gene dosage (to $I / i$, at $23^{\circ} \mathrm{C}$ ) or the temperature (to $34^{\circ} \mathrm{C}$, with $I / I$ plants), a typical $\mathrm{HR}$ can be elicited in at least some of the plants. In all of the $I / i$ plants held at $23^{\circ} \mathrm{C}$, there are pinpoint necrotic lesions (pnl) on the inoculated leaf (although still no detectable viral coat protein), but there are neither symptoms nor detectable coat protein in upper, uninoculated leaves. In these cases, the virus is confined to the inoculated leaf, where there is an effective IR and an HR. Finally, by altering conditions still more (e.g., $I / i$ plants at $34^{\circ} \mathrm{C}$ ), the third response type can be elicited. The IR in the inoculated leaf is lost or significantly reduced, resulting in detectable viral coat protein as well as local lesions. In addition, virus spreads to, and replicates in, upper leaves, causing a systemic vascular necrosis (vn) in the phloem tissue (an HR) that eventually kills the plant. Note that at the intermediate conditions between those eliciting the second and third response types (i.e., plants with double $I$ gene dose $[I / I]$ at high temperature $\left.\left[34^{\circ} \mathrm{C}\right]\right)$, half of the plants show each of the

Table 1. Symptoms and accumulation of Bean common mosaic virus (BCMV) NY-15 coat protein in inoculated primary leaves and uninoculated trifoliates of Phaseolus vulgaris BT-1, BT-2, and (BT-2 $\times$ BT-1) $\mathrm{F}_{1}$ plants $^{\mathrm{a}}$

\begin{tabular}{|c|c|c|c|c|c|c|c|c|c|}
\hline \multirow[b]{2}{*}{ Temperature } & \multicolumn{3}{|c|}{ BT-1 (genotype I/I) } & \multicolumn{3}{|c|}{$\left(\right.$ BT-1 $\times$ BT-2) F $_{1}($ genotype $I / i)$} & \multicolumn{3}{|c|}{ BT-2 (genotype $i / i$ ) } \\
\hline & $\operatorname{Sym}^{\mathrm{b}}$ & $\mathbf{P L}^{\mathrm{c}}$ & $\mathbf{U T}^{\mathbf{d}}$ & Sym & PL & UT & Sym & PL & UT \\
\hline $23^{\circ} \mathrm{C}$ & $--/--$ & $0.045 \pm 0.007^{\mathrm{e}}$ & $0.022 \pm 0.015(4)^{\mathrm{e}}$ & pnl/-- & $0.029 \pm 0.004$ & $0.066 \pm 0.017$ (4) & $\mathrm{cl} / \mathrm{m}$ & $1.543 \pm 0.11^{*}$ & $1.823 \pm 0.177 *(2)$ \\
\hline $34^{\circ} \mathrm{C}$ & $\begin{array}{l}\mathrm{pnl} /-- \\
\mathrm{pnl} / \mathrm{vn}\end{array}$ & $\begin{array}{l}0.049 \pm 0.007 \\
0.050 \pm 0.009\end{array}$ & $\begin{array}{l}0.061 \pm 0.014(6) \\
0.305 \pm 0.168^{*}(5)\end{array}$ & $\mathrm{pnl} / \mathrm{vn}$ & $0.190 \pm 0.096^{*}$ & $0.557 \pm 0.125 *(11)$ & $\mathrm{cl} / \mathrm{m}$ & $1.082 \pm 0.018^{*}$ & $1.511 \pm 0.051 *(2)$ \\
\hline
\end{tabular}

${ }^{a}$ All plants sampled 6 days postinoculation.

${ }^{\mathrm{b}}$ Sym = Symptoms, local/systemic: -- = no symptoms, cl = chlorotic spots, $\mathrm{m}=$ mosaic, $\mathrm{pnl}=$ pinpoint necrotic lesions, and vn = systemic vascular necrosis .

c $\mathrm{PL}=$ Primary inoculated leaves.

${ }^{\mathrm{d}} \mathrm{UT}=$ Uninoculated top trifoliate.

${ }^{\mathrm{e}}$ Values represent the mean absorbance $(405 \mathrm{~nm}) \pm$ standard deviation determined using enzyme-linked immunosorbent assay. Numbers in parentheses indicate the number of plants sampled. The asterisk indicates that the mean absorbance value is positive for the presence of BCMV antigen, defined as any value above the mean absorbance value for mock-inoculated control plants plus three standard deviations. 
The observations reported here contribute to a growing appreciation of the complexity of the interaction between a potentially resistant plant and a potential viral pathogen. While a predictable plant-pathogen response, whether that be extreme resistance or hypersensitive resistance, can be elicited when plant cultivar, resistance allele dosage, viral strain, and environmental conditions (including temperature, light intensity, and humidity) are carefully controlled, the variability possible when they are not can extend from one end of the resistance continuum (extreme resistance) to the other (systemic vascular necrosis and plant death). Our model for the interaction between BCMV and bean plants carrying the $I$ allele is a battle between plant and pathogen that is one of quantity and relative timing, in which the outcome depends on the relative accumulation across time of inhibitory molecules produced by the plant versus viral molecules produced by the pathogen. Our model is compatible with that proposed by Bendahmane et al. (1999) to explain the separate virus resistance and cell death responses mediated by the $R x$ gene of potato in interaction with PVX. In the interaction between BCMV and the $I$ allele, rapid activation of resistance in an $I / I$ plant at $23^{\circ} \mathrm{C}$ favors the plant and leads to extreme resistance; slower activation in an $I / i$ plant at higher temperature favors the pathogen, allowing the virus to escape the IR and to move just ahead of a spreading hypersensitivity (HR), resulting in systemic vascular necrosis and eventual plant death.

The fact that the balance between plant and pathogen can so easily shift suggests caution in classifying types of resistance (e.g., extreme resistance versus hypersensitive resistance) as well as in predicting the cellular responses supposedly associated with those labels. For instance, it was once widely accepted that resistance is expressed in protoplasts derived from plants with extreme resistance, but that it is not expressed in those derived from plants showing hypersensitive resistance

\section{A}

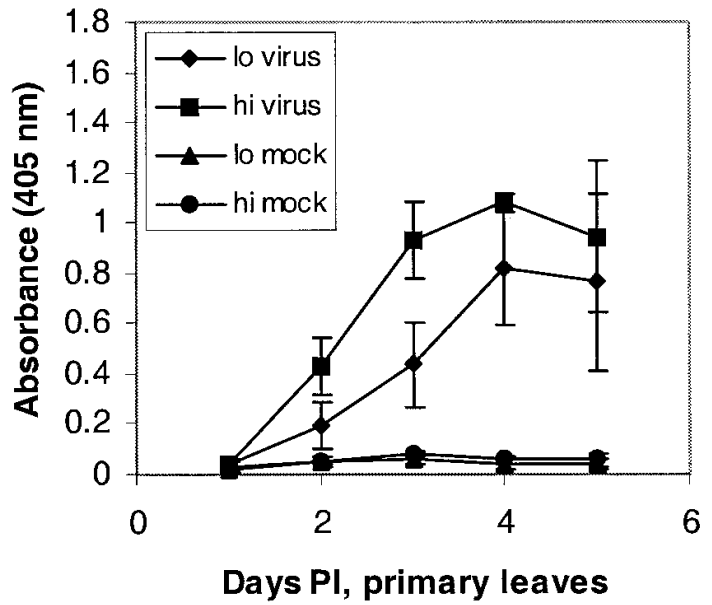

(Otsuki et al. 1972; Barker and Harrison 1984; Adams et al. 1985, 1986). From the emerging understanding that these are not two distinct and immutable resistance types, but instead represent two different points along a continuum of possible responses, it follows that cellular responses are unlikely to be so black and white. For instance, while resistance to PVX is expressed in protoplasts carrying the extreme resistance gene $R x$, that resistance is not expressed until after at least an 8-h lag (Köhm et al. 1993). Second, the difficulty in labeling the response to PVY of potato protoplasts carrying the "extreme resistance" gene $R y_{\text {sto }}$ is apparent in the different conclusions of two groups, with Barker and Harrison (1984) concluding that resistance is, and Hinrichs et al. (1998) concluding that resistance is not, expressed there. (While in both cases it is apparent that viral replication occurred in protoplasts of resistant plants, it was much more limited in comparison to the level of replication in a susceptible cultivar.) Finally, how, as well as when, one examines the reaction in question is obviously critical, as pointed out by Kim and Palukaitis (1997) in discussion of apparently discrepant data showing a clear IR against CMV after a 15-h lag in protoplasts isolated from hypersensitive resistant cowpeas. Whereas Gonda and Symons (1979), also studying CMV in protoplasts from hypersensitive resistant cowpeas, had earlier observed no inhibition of viral coat protein accumulation for $50 \mathrm{~h}$ postinoculation, those investigators had observed a severe drop in the rate of coat protein synthesis after $15 \mathrm{~h}$, possibly the same IR as observed by Kim and Palukaitis (1997).

What is now apparent is that many factors, including resistance gene dosage, temperature (and other environmental conditions), virus isolate, plant cultivar, and simultaneous infection with other viruses (Jayasinghe et al. 1989), can influence both the ultimate outcome of a particular virus-host interaction as well as the host phenotypes observed as that interac-

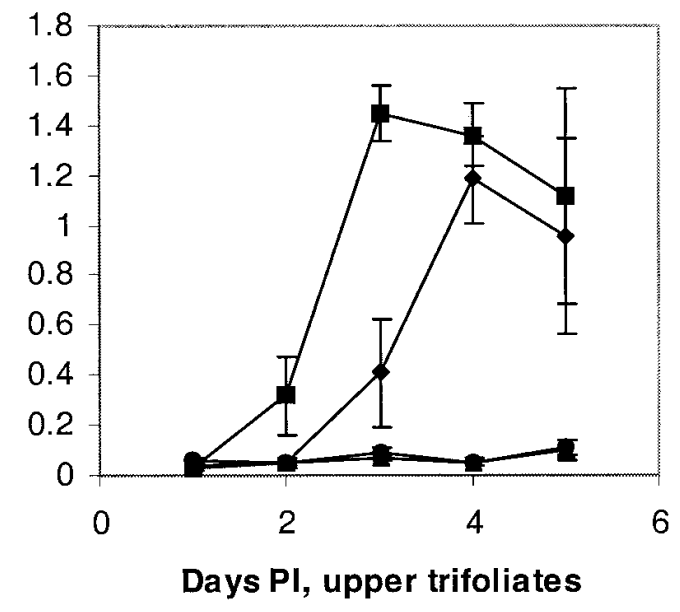

Fig. 1. Accumulation postinoculation (PI) of Bean common mosaic virus (BCMV) NY-15 coat protein in A, inoculated primary leaves and B, uppermost top trifoliates of Phaseolus vulgaris BT-2 plants at two different temperatures $\left(1 \mathrm{o}=24^{\circ} \mathrm{C}\right.$; hi $\left.=34^{\circ} \mathrm{C}\right)$. Coat protein accumulation was measured using direct double-antibody sandwich-enzyme-linked immunosorbent assay. Values represent the mean absorbance (at $405 \mathrm{~nm}$ ) \pm standard deviation of 10 BCMV NY15-inoculated plants (virus) and five buffer-inoculated plants (mock) per day per temperature. 
tion unfolds across time. Such complexity dictates care in how, as well as when, one analyzes the interaction.

\section{ACKNOWLEDGMENTS}

CWC gratefully acknowledges helpful discussions with A. Maule, D. Baulcombe, A. Bendahmane, G. Brigneti, I. Malcuit, and other members of the Department of Virus Research and the Sainsbury Laboratory of the John Innes Centre, Norwich, England. This work was supported by USDA NRICGP Awards \#92-37311-8062 and \#97-35311-4822 to CWC, and USDA NRICGP Award \#94-37300-0333 to MJ. MFM was supported by a NSF/DOE/USDA Plant Science Center fellowship, a DOE/NSF/USDA Interagency Research Training Grant, and grants from Sigma Xi, the President's Council for Cornell Women, and the Association for Women in Science. We gratefully acknowledge N. O'Leary and L. Gildensoph for help with statistical analysis and computer graphing, G. Moriarty and C. Morehouse for technical support, and R. Provvidenti for the viral isolate.

\section{LITERATURE CITED}

Adams, S. E., Jones, R. A. C., and Coutts, R. H. A. 1985. Infection of protoplasts derived from potato shoot cultures with potato virus X. J. Gen. Virol. 66:1341-1346.

Adams, S. E., Jones, R. A. C., and Coutts, R. H. A. 1986. Expression of potato virus $\mathrm{X}$ resistance gene $R x$ in potato leaf protoplasts. J. Gen. Virol. 67:2341-2345.

Ali, M. A. 1950. Genetics of resistance to the common bean mosaic virus (bean virus 1) in the bean (Phaseolus vulgaris L.). Phytopathology 40:69-79.

Bagnall, R. H. 1961. Recovery of virus X from leaves of graftinoculated immune potato plants. Phytopathology 51:338-340.

Barker, H., and Harrison, B. D. 1984. Expression of genes for resistance to potato virus $\mathrm{Y}$ in potato plants and protoplasts. Ann. Appl. Biol. 105:539-545.

Bendahmane, A., Kanyuka, K., and Baulcombe, D. C. 1999. The $R x$ gene from potato controls separate virus resistance and cell death responses. Plant Cell 11:781-791.

Benson, A. P., and Hooker, W. J. 1960. Isolation of virus X from "immune" varieties of potato, Solanum tuberosum. Phytopathology 50:231-234.

Clark, M. F., and Adams, A. N. 1977. Characteristics of the microplate method of enzyme-linked immunosorbent assay for the detection of plant viruses. J. Gen. Virol. 34:475-483.

Cockerham, G. 1970. Genetical studies on resistance to potato viruses X and Y. Heredity 25:309-348.

Cooper, J. I., and Jones, A. T. 1983. Responses of plants to viruses: Proposals for the use of terms. Phytopathology 73:127-128.

Culver, J. N., Lindbeck, A. G. C., and Dawson, W. O. 1991. Virus-host interactions: Induction of chlorotic and necrotic responses in plants by tobamoviruses. Annu. Rev. Phytopathol. 29:193-217.

Dangl, J. L., Dietrich, R. A., and Richberg, M. H. 1996. Death don't have no mercy: Cell death programs in plant-microbe interactions. Plant Cell 8:1793-1807.

Delhey, R. 1974. Zur Natur der extremen Virusresistenz bei der Kartoffel. I. Das X-Virus. Phytopathol. Z. 80:97-119.

Delhey, R. 1975. Zur Natur der extremen Virusresistenz bei der Kartoffel. II. Das Y-Virus. Phytopathol. Z. 82:163-168.
Fisher, M. L. 1995. The genetics and evolution of potyvirus-host gene interactions in Phaseolus vulgaris L. Ph.D. thesis. Cornell University, Ithaca, NY, U.S.A.

Fisher, M. L., and Kyle, M. M. 1994. Inheritance of resistance to potyviruses in Phaseolus vulgaris L. III. Cosegregation of phenotypically similar dominant responses to nine potyviruses. Theor. Appl. Genet. 89:818-823.

Gonda, T. J., and Symons, R. H. 1979. Cucumber mosaic virus replication in cowpea protoplasts: Time course of virus, coat protein and RNA synthesis. J. Gen. Virol. 45:723-736.

Goodman, R. N., and Novacky, A. J. 1994. The Hypersensitive Reaction in Plants to Pathogens: A Resistance Phenomenon. American Phytopathological Society, St. Paul, MN.

Greenberg, J. T. 1997. Programmed cell death in plant-pathogen interactions. Annu. Rev. Plant Physiol. Plant Mol. Biol. 48:525-545.

Grogan, R. G., and Walker, J. C. 1948. The relation of common mosaic to black root of bean. J. Agric. Res. (Washington, DC) 77:315-331.

Hammond-Kosack, K. E., and Jones, J. D. G. 1996. Resistance genedependent plant defense responses. Plant Cell 8:1773-1791.

Hinrichs, J., Berger, S., and Shaw, J. G. 1998. A hypersensitive response-like mechanism is involved in resistance of potato plants bearing the $R y_{\text {sto }}$ gene to the potyviruses potato virus $\mathrm{Y}$ and tobacco etch virus. J. Gen. Virol. 79:167-176.

Jayasinghe, U., Chuquillanqui, C., and Salazar, L. F. 1989. Modified expression of virus resistance in potato in mixed virus infections. Am. Potato J. 66:137-144.

Jenkins, W. A. 1940. A new virus disease of snap beans. J. Agric. Res. (Washington, DC) 60:279-288.

Jenkins, W. A. 1941. A histological study of snap bean tissues affected with black root. J. Agric. Res. (Washington, DC) 62:683-690.

Kim, C.-H., and Palukaitis, P. 1997. The plant defense response to cucumber mosaic virus in cowpea is elicited by the viral polymerase gene and affects virus accumulation in single cells. EMBO J. 16:4060-4068.

Köhm, B. A., Goulden, M. G., Gilbert, J. E., Kavanagh, T. A., and Baulcombe, D. C. 1993. A potato virus X resistance gene mediates an induced, nonspecific resistance in protoplasts. Plant Cell 5:913-920.

Matthews, R. E. F. 1991. Plant Virology. 3rd ed. Academic Press, San Diego, CA, U.S.A.

Otsuki, Y., Shimomura, T., and Takebe, I. 1972. Tobacco mosaic virus multiplication and expression of the $N$ gene in necrotic responding tobacco varieties. Virology 50:45-50.

Pierce, W. H. 1934. Viroses of the bean. Phytopathology 24:87-115.

Pierce, W. H. 1935. The inheritance of resistance to common bean mosaic in field and garden beans. Phytopathology 25:875-883.

Ponz, F., and Bruening, G. 1986. Mechanisms of resistance to plant viruses. Annu. Rev. Phytopathol. 24:355-381.

Ponz, F., Glascock, C. B., and Bruening, G. 1988. An inhibitor of polyprotein processing with the characteristics of a natural virus resistance factor. Mol. Plant-Microbe Interact. 1:25-31.

Takusari, H., and Takahashi, T. 1979. Studies on viral pathogenesis in host plants. IX. Effect of citrinin on the formation of necrotic lesion and virus localization in the leaves of 'Samsun NN' tobacco plants after tobacco mosaic virus infection. Phytopathol. Z. 96:324-329.

Valkonen, J. P. T. 1994. Natural genes and mechanisms for resistance to viruses in cultivated and wild potato species (Solanum spp.). Plant Breed. 112:1-16.

Yu, I.-C., Parker, J., and Bent, A. F. 1998. Gene-for-gene disease resistance without the hypersensitive response in Arabidopsis dndl mutant. Proc. Natl. Acad. Sci. USA 95:7819-7824. 